\section{Kidney \\ Blood Pressure \\ Research}

Review

This is an Open Access article licensed under the terms of the Creative Commons Attribution-

\title{
Renal and Extrarenal Effects of Gum Arabic (Acacia Senegal) - What Can be Learned from Animal Experiments?
}

\author{
Omaima Nasir \\ Department of Medical Laboratory, Faculty of Medical Applied Sciences, Turabah,Taif University
}

\section{Key Words}

Chronic renal disease - Plasma phosphate concentration - Proteinuria - Obesity • Diabetes • Colon carcinoma $\bullet$ Inflammation

\begin{abstract}
Gum arabic (GA), a water-soluble dietary fiber rich in $\mathrm{Ca}^{2+}, \mathrm{Mg}^{2+}$ and $\mathrm{K}^{+}$, is used in Middle Eastern countries for the treatment of patients with chronic kidney disease. Recent animal experiments shed some light into mechanisms involved in the therapeutic action of GA. According to experiments in healthy mice, GA treatment increases creatinine clearance, enhances renal excretion of $\mathrm{ADH}, \mathrm{Mg}^{2+}$ and $\mathrm{Ca}^{2+}$, decreases plasma phosphate concentration as well as urinary excretion of phosphate and $\mathrm{Na}^{+}$. In diabetic mice GA treatment increases urinary $\mathrm{Ca}^{2+}$ excretion, and decreases plasma phosphate concentration, plasma urea concentration, urinary flow rate, natriuresis, phosphaturia, glucosuria, proteinuria as well as blood pressure. Extrarenal effects of GA treatment in mice include decreased expression of intestinal $\mathrm{Na}^{+}$ coupled glucose carrier SGLT1 with subsequent delay of electrogenic intestinal glucose transport, glucose-induced hyperglycemia, hyperinsulinemia and body weight gain. GA treatment decreases colonic transcription of the angiogenetic factors angiogenin 1 , angiogenin 3 and angiogenin 4, of CD38 antigen, aquaporin4, interleukin18, vav-3-oncogene, $\mathrm{y}^{+}$-amino acid-transporter, sulfatase1, ubiquitinD and chemokine ligand5. Moreover, GA treatment decreases angiogenin and B-catenin protein expression. Accordingly, GA treatment counteracts the development of tumors following chemical cancerogenesis. In mouse dendritic cells, antigen-presenting cells linking innate and adaptive immunity, GA treatment modifies maturation and cytokine release. GA treatment further favourably influences the course of murine malaria. The effects of GA treatment on plasma phosphate concentration, blood pressure and proteinuria may prove beneficial in chronic renal failure and diabetic nephropathy. The effect of GA on intestinal glucose transport may be useful in the prophylaxis and treatment of obesity and diabetes, the effect of GA on angiogenin and B-catenin expression could be exploited for the prophylaxis against colon carcinoma, the effects of GA on angiogenin expression and dendritic cells may be useful in the treatment of inflammatory disease and malaria.
\end{abstract}




\section{Kidney Blood Pressure Research}

\begin{tabular}{l|l}
\hline Kidney Blood Press Res 2013;37:269-279 \\
\hline DOI: $10.1159 / 000350152$ & (c) 2013 S. Karger AG, Basel
\end{tabular}

Published onIne: August 11, 2013 www.karger.com/kbr

Nasir: Effects of Gum Arabic

\section{Introduction}

Gum Arabic (GA), a water-soluble dietary fiber [1], is a polysaccharide with branched chains of (1-3) linked $\beta$-D-galactopyranosyl units containing $\alpha$-L-arabinofuranosyl, $\alpha$-Lrhamnopyranosyl, $\beta$-D-glucuronopyranosyl and 4-0-methyl- $\beta$-D-glucuronopyranosyl units [2]. GA is rich in $\mathrm{Ca}^{2+}, \mathrm{K}^{+}$and $\mathrm{Mg}^{2+}$ [2]. GA is fabriacted from the dried gummy exudates from the stems and branches of Acacia senegal [3]. In the colon GA is degraded by microorganisms to short chain fatty acids [4]. According to the US Food and Drug Administration GA is one of the safest dietary fibers [5]. GA is in Middle Eastern countries used for the treatment of patients with chronic kidney disease and end-stage renal disease [6]. Efficacy of GA has, however, been a matter of controversy [7]. Earlier studies yielded evidence for and against an antioxidant effect of GA as well as protective effects in experimental hepatic-, renal- and cardiac toxicity [7]. GA has ben shown to decrease blood pressure [8], to decrease plasma cholesterol concentrations in rats [7], to foster dental remineralization [7], to displays antimicrobial activity [7] and to stimulate intestinal absorption thus counteracting diarrhoea [7].

The present review discusses more recent animal studies revealing some renal and extrarenal effects of gum arabic. The reader is encouraged to refer to a previous review addressing earlier experimental evidence on physiological GA effects [7]. The source product of gum Arabic (AlManna) used in these studies are from DarSavanna/Nature Gums Co Sudan) www.darsavanna.com.

\section{Renal effects of Gum Arabic}

\section{Healthy mice}

In healthy mice, addition of $10 \%$ GA to the dinking water has been shown to enhance creatinine clearance, renal ADH excretion as well as intestinal and renal excretion of $\mathrm{Mg}^{2+}$ and $\mathrm{Ca}^{2+}[9]$. GA treatment decreased plasma concentration of $1,25(\mathrm{OH})_{2} \mathrm{D}_{3}$ as well as urinary excretion of phosphate and sodium [9]. GA treatment did not significantly modify food intake but increased fecal dry weight. GA treatment resulted in a significant reduction of the urine volume despite constant fluid intake [9]. The antidiuresis was paralleled by an increase in urinary ADH excretion [9]. GA treatment increased fecal $\mathrm{Na}^{+}$excretion, an effect presumably due to binding of $\mathrm{Na}^{+}$to $\mathrm{GA}$ and thus impairment of intestinal $\mathrm{Na}^{+}$absorption [9]. Along those lines GA treatment decreased urinary $\mathrm{Na}^{+}$and $\mathrm{Cl}^{-}$excretion. GA treatment increased plasma $\mathrm{Na}^{+}$- and $\mathrm{Cl}^{-}$-concentration but did not significantly modify plasma aldosterone concentration and systolic blood pressure [9]. GA treatment enhanced urinary and fecal $\mathrm{Ca}^{2+}$ excretion, an effect at least partially due to increased intestinal $\mathrm{Ca}^{2+}$ intake due to the high $\mathrm{Ca}^{2+}$ content of GA [9] (Fig. 1). Possibly due to increased $\mathrm{Ca}^{2+}$ intake, GA decreased plasma concentrations of 1,25-dihydroxy vitamin $\mathrm{D}\left(1,25(\mathrm{OH})_{2} \mathrm{D}_{3}\right)$ and tended to decrease plasma parathyroid hormone (iPTH) concentration [9], which would be expected to reduce renal tubular $\mathrm{Ca}^{2+}$ reabsorption and thus contribute to calciuria $[10,11]$. Possibly in part due to decreasing $1,25(\mathrm{OH})_{2} \mathrm{D}_{3}$ and due to decreasing PTH levels [12], GA treatment significantly reduced urinary phosphate excretion [9] (Fig. 1). GA treatment increased the 24h-creatinine clearance as a measure of glomerular filtration rate [9]. The effect may at least in theory be due to formation of short-chain fatty acids such as butyrate [13], which are produced during GA degradation by intestinal bacteria [14] and which have been shown to increase glomerular filtration rate and renal blood flow [15].

\section{Diabetic mice}

As diabetic nephropathy is a major cause of end-stage renal disease [16-19], additional studies were performed on GA in diabetic animals [20], i.e. in heterozygous Akita ( $\mathrm{kital}^{-/+}$) mice developing spontaneous diabetes due to gradual destruction of the pancreatic ß-cells [21]. GA treatment of the akita $/$ mice tended to slightly blunt the hyperglycemia, an effect, however, not reaching statistical significance. GA significantly decreased food and fluid intake but did not significantly modify body weight of $a_{k i t a /-}$ mice [20]. 


\section{Kidney \\ Blood Pressure Research}

Fig. 1. Effect of Gum Arabic (GA) treatment on plasma concentration and urinary excretion of $\mathrm{Ca}^{2+}$ and phosphate in diabetic mice. Arithmetic means \pm SEM of plasma concentrations (left panels) and urinary excretions (right panels) of $\mathrm{Ca}^{2+}$ (upper panels) and phosphate (lower panels) in diabetic heterozygous Akita mice $\left(\right.$ akita $\left.^{+/}\right)$without (white bars) and with 1 week (grey bars) or 2 weeks (black bars) GA treatment. *indicates significant difference from control (without GA treatment). Modified from Nasir et al. 2012.
Kidney Blood Press Res 2013;37:269-279

\begin{tabular}{l|l}
\hline DOI: $10.1159 / 000350152$ & (C) 2013 S. Karger AG, Basel
\end{tabular}

Publisned ontIne: August 11, 2013 www.karger.com/kbr
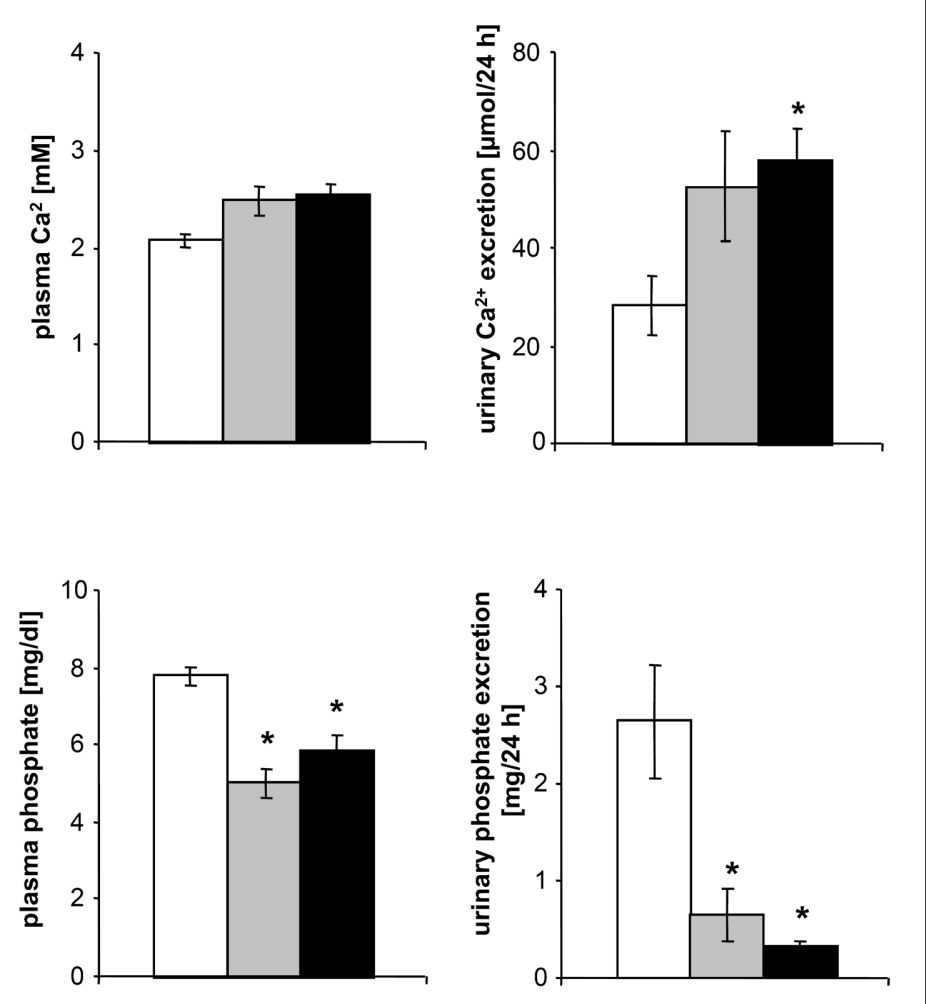

GA treatment significantly reduced urinary glucose excretion, $\mathrm{Na}^{+}$excretion and urinary volume [20]. The reduced glucosuria presumably contributed to the blunted diuresis and urinary $\mathrm{Na}^{+}, \mathrm{K}^{+}$and urea excretion. Glucosuria causes osmotic diuresis with subsequent renal loss of electrolytes [22]. The stimulating effect of GA treatment on release of ADH [9] would similarly be expected to decrease fluid, $\mathrm{Na}^{+}$and urea excretion. GA tended to decrease urinary $\mathrm{K}^{+}$excretion following GA treatment, an effect, however, not reaching statistical significance [20]. GA tratment did not affect plasma $\mathrm{Na}^{+}$concentration or plasma $\mathrm{K}^{+}$concentration of the akita $^{+/}$mice. GA treatment decreased plasma urea concentration and fractional urea excretion but did not significantly modify plasma aldosterone concentration [20]. In $\mathrm{akita}^{+/-}$ mice GA treatment was followed by a marked and significant decrease of arterial blood pressure [20].

Similar to what has been seen in healthy mice (see above), GA treatment of akita $^{+/}$mice significantly increased the urinary excretion of $\mathrm{Ca}^{2+}[20]$. GA treatment tended to increase plasma $\mathrm{Ca}^{2+}$ concentration, an effect, however, not reaching statistical significance [20] (Fig. 1). GA treatment of akita $^{+/}$mice was followed by a marked and significant decrease of plasma phosphate concentration [20] (Fig. 1), which may be due to the decrease of the plasma $1,25(\mathrm{OH})_{2} \mathrm{D}_{3}$ concentration [20]. The hypophosphatemia is in turn expected to result in antiphosphaturia, which has indeed been observed in healthy [9] and diabetic [20] animals. The decrease of plasma phosphate concentration is likely to increase the plasma concentration of ionized $\mathrm{Ca}^{2+}$ and thus to counteract hyperparathyroidism, a major pathophysiological parameter in advanced renal disease [23-25].

Diabetic akita $^{+/}$mice suffered from albuminuria, which was significantly decreased by GA treatment [20] (Fig. 2). The decrease of albuminuria could have been due to a decrease of blood pressure. In contrast to healthy animals [9], GA significantly decreased blood pressure in diabetic animals [20] (Fig. 2). The effect of GA on blood pressure may have resulted from enhanced absorption of $\mathrm{Ca}^{2+}$, which may lower blood pressure due to stimulation of the $\mathrm{Ca}^{2+}$-sensing receptor with subsequent vasodilation [26] and natriuresis due to inhibition of $\mathrm{Na}^{+}, \mathrm{K}^{+}, 2 \mathrm{Cl}^{-}$cotransport in the thick ascending limb [27]. Whatever mechanism involved, the 


\section{Kidney Blood Pressure Research}

Fig. 2. Effect of gum arabic (GA) treatment on blood pressure and albumin excretion in diabetc mice. Arithmetic means \pm SEM of systolic arterial blood pressure (left panel) and urinary albumin excretion (right panel) in diabetic heterozygous Akita mice $\left(\right.$ akita $\left.^{+/}\right)$without (white bars) and with 1 week (grey bars) or 2 weeks

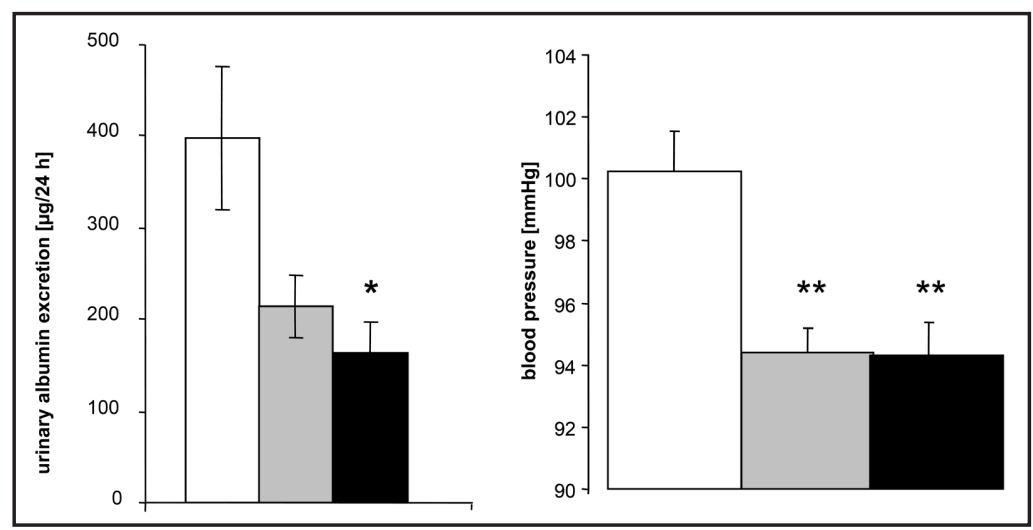
(black bars) GA treatment. *indicates significant difference from control (without GA treatment). Modified from Nasir et al. 2012.

decrease of proteinuria may delay the progression of renal disease [28], as proteinuria is an important parameter for the progression of renal disease [28-37].

\section{Mice suffering from renal failure}

GA treatment increased fecal nitrogen excretion [38], decreased oxygen radical formation [6], and modestly counteracted the renal injury following acute gentamicin-nephrotoxicity in rats [39]. A 4 weeks treatment with adenine increased the pro-inflammatory cytokine TNF- $\alpha$, and, according to glutathione and superoxide dismutase, triggered oxidative stress [40]. Adenine treatment decreased the creatinine clearance and increased the plasma urea and creatinine cocnentrations, effects significantly blunted by additional GA treatment [41]. Adenine caused marked renal damage, effects ameliorated by GA treatment for four consecutive weeks. GA reversed the decrease in body weight and the glomerular, tubular and interstitial renal lesions following adenine treatment [40]. It has been argued that those effects of GA may favourably influence the clinical course of chronic renal disease [40].

\section{Extrarenal effects of GA}

\section{Effect on intestinal transport}

GA has been shown to enhance intestinal water and $\mathrm{Na}^{+}$absorption in a rat model of chronic-osmotic diarrhea thus favouring rehydration [42]. Apparently, the effects of GA on intestinal $\mathrm{Na}^{+}$and water absorption are dependent on the condition of the intestine. The waterholding capacity of dietary fibers [43] may have opposite consequences in intact intestine and during diarrhea.

GA treatment has been shown to decrease intestinal $\mathrm{Na}^{+}$coupled glucose transport by downregulating the $\mathrm{Na}^{+}$coupled glucose carrier SGLT1 [44], which determines the rate of intestsinal glucose absorption [45] and thus influences glucose-induced insulin release and development of obesity (Fig. 3). Addition of GA to the drinking water of C57Bl/6 mice significantly decreased SGLT1 protein abundance in jejunal and ileal brush border membrane vesicles [44]. According to gene array data, GA does not decrease SGLT1 protein expression by inhibiting SGLT1 transcription but modies SGLT1 abundance rather by modifying posttranscriptional regulation [44]. Besides altered transcription [46] or mRNA stability [47], SGLT1 could be modified by trafficking into the plasma membrane [48] or by direct regulation of transporter activity [49]. SGLT1 activity is influenced by carbohydraterich diet [50], adrenergic innervation [51], insulin [52] glucagon-like peptide 2 [53], cholecystokinin [48], and insulin-like growth factors [54]. Signaling of SGLT1 regulation includes phosphatidylinositol (PI) 3 kinase [55], phosphoinositide-dependent kinase 1 (PDK1) [56] as well as the serum-and glucocorticoid-regulated kinase isoforms SGK1 [57, 58] and SGK3 [59]. SGLT1 activity is further subject to downregulation by the 67-kDa-protein RS1 [60, 61]. 


\section{Kidney \\ Blood Pressure Research}

According to gene array analysis, decreased SGLT1 protein abundance following GA treatment could be secondary to enhanced expression of SGLT1 inhibitor RS1 (encoded by rsc1a1) [60] or downregulation of SGLT1 stimulator SGK3 [44].

According to Ussing chamber experiments electrogenic glucose transport is similarly decreased by GA treatment [44]. In those studies [44] GA treatment did, however, not significantly modify electrogenic transport of phenylalanine, methionine, glutamine or proline. GA treatment did not significantly alter food intake and only slightly decreased fluid intake [44]. Addition of $20 \%$ glucose to the drinking water significantly increases body weight and fasting plasma glucose concentrations, effects significantly blunted by simultaneous treatment with GA.

Earlier studies showed that in contrast to chronic GA treatment, direct application of GA to perfused jejunal segments did not influence intestinal glucose uptake [62].

Presumbly due to downregulation of SGLT1 activity GA treatment blunts hyperglycemic effect of excessive glucose intake [44]. Dietary fibres were shown to decrease body weight [63], to prevent metabolic syndrome [64] and to improve glycemic control as well as hyperinsulinemia in type II diabetes [65]. The effect of dietary fibers has been attributed to interaction with food intake and body weight through satiety, glycemia and insulinemia, blood lipids and blood pressure [66].

In humans GA treatment indeed modifies body weight [67]. GA treatment decreases body mass index and body fat percentage among healthy adult females, and effect, which could be exploited in the treatment of obesity [67].

The effect of GA on obesity in humans may possibly be in part due to an influence on satiety [68]. GA treatment decreases the caloric intake and increases the subjective ratings of feeling satiated [68].

\section{Anticarcinogenic effect}

GA treatment modifies in colonic tissue the transcript levels of several genes known to be important for cell proliferation and/or tumor growth, such as CD38 antigen [69], interleukin 18 [70], vav 3 oncogene [71], Solute carrier family 7, member 9 [72], sulfatase 1 $[73,74]$, ubiquitin D [75] and chemokine (C-C motif) ligand 5 [76]. Moreover, GA treatment decreases the protein abundance of $ß$-catenin, a powerful oncogene in colonic tumors [77, 78]. The altered expression of these and additional genes could lead to inhibition of tumor growth during GA treatment.

GA-treatment further decreases angiogenin protein expression (Fig. 3) and ß-catenin expression [79]. Chemical cancerogenesis by intraperitoneal injection of $20 \mathrm{mg} / \mathrm{kg}$ 1,2-dimethylhydrazine followed by 3 cycles of 3\% dextrane sodium sulphate in drinking water results in the development of multiple colonic tumors, an effect significantly blunted by GA treatment [79]. Those observations disclose a powerful anticarcinogenic effect of GA treatment, which could be exploited for prophylaxis or treatment of colon carcinoma [79].

Nutritional intake of several dietary fibers has previously been claimed to confer protection against colonic, prostate and rectal cancer [80]. However, the effect of fiber-containing nutrients on the incidence of colon cancer has been questioned [81]. Thus, a generalized claim that dietary fiber protects against the development of colon cancer is not supported by the presently available evidence.

The observation thatGAinfluences the expression of angiogenins, provides an explanation for the protective effect of GA on tumor growth. However, the involvement of further mechanisms cannot be ruled out. GA is fermented under the influence of microorganisms in the colon to short chain fatty acids [4], which may counteract inflammation and tumor growth [82-85]. Moreover, short chain fatty acids have been shown to influence oncogene expression [86-88].

\section{Effect on dendritic cells}

Besides their role in tumor growth, angiogenins are known to participate in inflammatory responses in a wide variety of tissues [89-95] including inflammatory bowel disease [96]. The 


\section{Kidney Blood Pressure Research}

Fig. 3. Cartoon illustrating the intestinal effects of gum arabic. GA = gum arabic, SGLT1 = sodium coupled glucose transporter, DCs = dendritic cells.
Kidney Blood Press Res 2013;37:269-279

\begin{tabular}{|l|l}
\hline DOI: 10.1159/000350152 & (c) 2013 S. Karger AG, Basel \\
\hline
\end{tabular}

Publisned oninne: August 11, 2013 www.karger.com/kbr

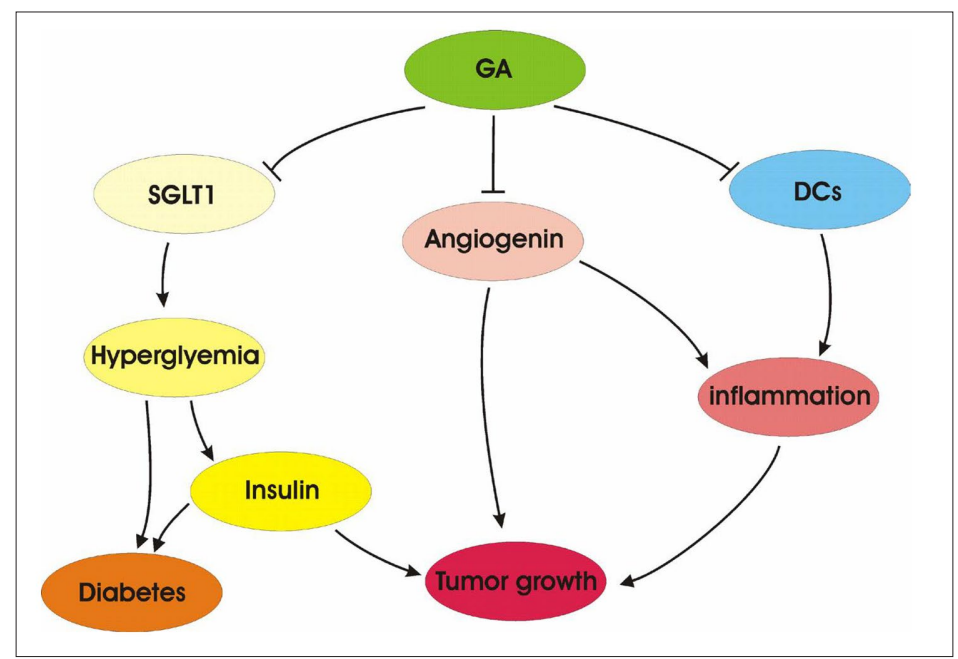

effect of GA on angiogenin expression could thus exert antiinflammatory effects. Moreover, GA may influence inflammation by interacting with include intestinal dendritic cells (DCs), which are in direct contact with the intestinal lumen [97] (Fig. 3). DCs are antigen-presenting cells contributing to both innate and adaptive immunity and thus playing a decisive role in the regulation of the immune response [98-107]. GA treatment of DCs is followed by upregulation of several maturation markers, such as CD86 [108] CD54 [109] and CD40 [110, 111]. Low expression levels of CD86 and CD40 are characteristic of a tolerogenic DC phenotype [110]. GA exposure further leads to upregulation of MHC II, which is critically important for antigen presentation [112].

GA treatment further stimulates formation of the interleukins 6 (IL-6), 10 (IL-10) and 12 (IL-12p70) as well as TNF $\alpha$ with a particularly strong effect on IL-10 formation. The cytokines are important regulators of the immune response [113-115]. IL-10 suppresses DC function thus rendering them tolerant [116] Moreover, IL-10 is a negative feedback inhibitor of exuberant $\mathrm{T}$ cell responses [115]. Thus, GA may exert anti-inflammatory effects by modifying $\mathrm{DC}$ function.

GA activates ERK1 and ERK2 [117] and decreases the phagocytic activity of DCs. GA treatment increases the percentage of $\mathrm{CD}^{+} \mathrm{CD} 8{ }^{+} \mathrm{T}$ cells and $\mathrm{CD} 45^{+} \mathrm{CD} 19^{+} \mathrm{B}$ cells in the spleen [117]. The observations reveal a powerful effect of GA on maturation of and cytokine release from DCs [117].

\section{Antimalarial effect}

GA treatment has been shown to favourably influence the clinical course of malaria in mice [118]. GA treatment slightly decreases the parasitaemia and extends the life span of $P$. berghei infected mice. GA thus favourably influences the clinical course of murine malaria [118]. The mechanism accounting for this effect remained, however, elusive [118].

\section{Conclusions}

Gum arabic (GA) has been used in the treatment of chronic renal failure. Animal experiments indeed reveal several favourable renal effects of GA including decrease of plasma phosphate concentration, lowering of blood pressure and reduction of proteinuria. Moreover, GA exerts several extrarenal effects with therapeutic potential, such as slowing of intestinal glucose transport, which may be useful in the prophylaxis and treatment of obesity and diabetes as well as decrease of angiogenin and ß-catenin expression, which may counteract development of colon carcinoma and inflammatory disorders. At this stage clinical studies are warranted to test whether similar beneficial effects could be accomplished in human disease. 


\section{Kidney \\ Blood Pressure Research}

\section{Acknowledgments}

The author was supported by a DAAD fellowship and DarSavanna/Nature Gums Co., Sudan ,www.darsavanna.com.

\section{References}

1 Tiss A, Carriere F, Verger R: Effects of gum arabic on lipase interfacial binding and activity. Anal Biochem 2001;294:36-43.

2 Deckwer WD, Dill B, Eisenbrand E, Bornscheuer U, Pühler A, Heiker FR, Kirschning A, Schreier P, Fugmann B, Pohnert G, Gamse T, Hulpke H: Römpp Online. Georg-Thieme-Verlag 2006;Stuttgart.

-3 Younes H, Garleb K, Behr S, Remesy C, Demigne C: Fermentable fibers or oligosaccharides reduce urinary nitrogen excretion by increasing urea disposal in the rat cecum. J Nutr 1995;125:1010-1016.

4 Phillips GO: Acacia gum (Gum Arabic): a nutritional fibre; metabolism and calorific value. Food Addit Contam 1998;15:251-264.

5 Anderson DM: Evidence for the safety of gum arabic (Acacia senegal (L.) Willd.) as a food additive--a brief review. Food Addit Contam 1986;3:225-230.

-6 Al Majed AA, Mostafa AM, Al Rikabi AC, Al Shabanah OA: Protective effects of oral arabic gum administration on gentamicin-induced nephrotoxicity in rats. Pharmacol Res 2002;46:445-451.

7 Ali BH, Ziada A, Blunden G: Biological effects of gum arabic: a review of some recent research. Food Chem Toxicol 2009;47:1-8.

8 Al Mosawi AJ: The challenge of chronic renal failure in the developing world: possible use of acacia gum. Pediatr Nephrol 2002;17:390-391.

-9 Nasir O, Artunc F, Saeed A, Kambal MA, Kalbacher H, Sandulache D, Boini KM, Jahovic N, Lang F: Effects of gum arabic (Acacia senegal) on water and electrolyte balance in healthy mice. J Ren Nutr 2008;18:230-238.

10 Friedman PA: Mechanisms of renal calcium transport. Exp Nephrol 2000;8:343-350.

11 Hoenderop JG, Nilius B, Bindels RJ: Molecular mechanism of active Ca2+ reabsorption in the distal nephron. Annu Rev Physiol 2002;64:529-549.

12 Murer H, Biber J: A molecular view of proximal tubular inorganic phosphate (Pi) reabsorption and of its regulation. Pflugers Arch 1997;433:379-389.

13 Matsumoto N, Riley S, Fraser D, Al Assaf S, Ishimura E, Wolever T, Phillips GO, Phillips AO: Butyrate modulates TGF-beta1 generation and function: potential renal benefit for Acacia(sen) SUPERGUM (gum arabic)? Kidney Int 2006;69:257-265.

14 Bliss DZ: Dietary fiber in conservative management of chronic renal failure. Pediatr Nephrol 2004;19:10691070.

15 Fioretto P, Trevisan R, Velussi M, Cernigoi A, De Riva C, Bressan M, Doria A, Pauletto N, Angeli P, De Dona C: Glomerular filtration rate is increased in man by the infusion of both D,L-3-hydroxybutyric acid and sodium D,L-3-hydroxybutyrate. J Clin Endocrinol Metab 1987;65:331-338.

16 Alter ML, Ott IM, von Websky K, Tsuprykov O, Sharkovska Y, Krause-Relle K, Raila J, Henze A, Klein T, Hocher B: DPP-4 inhibition on top of angiotensin receptor blockade offers a new therapeutic approach for diabetic nephropathy. Kidney Blood Press Res 2012;36:119-130.

-17 Deshmukh AB, Patel JK, Prajapati AR, Mishra B: Investigating the effect of CoCl2 administration on diabetic nephropathy and associated aortic dysfunction. Kidney Blood Press Res 2012;35:694-697.

-18 Tanhauserova V, Tomandl J, Pacal L, Kleparnik M, Maluskova D, Bartakova V, Kuricova K, Rehorova J, Stepankova S, Svojanovsky J, Olsovsky J, Belobradkova J, Krusova D, Jurajda M, Muzik J, Pavlik T, Kankova K: ADMA, SDMA and L-arginine/ADMA ratio but not DDAH genetic polymorphisms are reliable predictors of diabetic nephropathy progression as identified by competing risk analysis. Kidney Blood Press Res 2012;36:200-208.

19 Schernthaner G: Kidney disease in diabetology: lessons from 2007. Nephrol Dial Transplant 2008;23:11121115 .

20 Nasir O, Umbach AT, Rexhepaj R, Ackermann TF, Bhandaru M, Ebrahim A, Artunc F, Kempe DS, Puchchakayala G, Siraskar B, Foller M, Saeed A, Lang F: Effects of gum arabic (Acacia senegal) on renal function in diabetic mice. Kidney Blood Press Res 2012;35:365-372. 


\section{Kidney \\ Blood Pressure Research}

-21 Hong EG, Jung DY, Ko HJ, Zhang Z, Ma Z, Jun JY, Kim JH, Sumner AD, Vary TC, Gardner TW, Bronson SK, Kim JK: Nonobese, insulin-deficient Ins2Akita mice develop type 2 diabetes phenotypes including insulin resistance and cardiac remodeling. Am J Physiol Endocrinol Metab 2007;293:E1687-E1696.

-22 Lang F: Osmotic diuresis. Ren Physiol 1987;10:160-173.

-23 Albaaj F, Hutchison A: Hyperphosphataemia in renal failure: causes, consequences and current management. Drugs 2003;63:577-596.

-24 Silver J, Levi R: Cellular and molecular mechanisms of secondary hyperparathyroidism. Clin Nephrol 2005;63:119-126.

25 Cozzolino M, Brancaccio D, Gallieni M, Slatopolsky E: Pathogenesis of vascular calcification in chronic kidney disease. Kidney Int 2005;68:429-436.

-26 Weston AH, Absi M, Ward DT, Ohanian J, Dodd RH, Dauban P, Petrel C, Ruat M, Edwards G: Evidence in favor of a calcium-sensing receptor in arterial endothelial cells: studies with calindol and Calhex 231. Circ Res 2005;97:391-398.

27 Jung J, Foroud TM, Eckert GJ, Flury-Wetherill L, Edenberg HJ, Xuei X, Zaidi SA, Pratt JH: Association of the calcium-sensing receptor gene with blood pressure and urinary calcium in African-Americans. J Clin Endocrinol Metab 2009;94:1042-1048.

28 Abbate M, Zoja C, Remuzzi G: How does proteinuria cause progressive renal damage? J Am Soc Nephrol 2006;17:2974-2984.

29 Agarwal R: Vitamin D, proteinuria, diabetic nephropathy, and progression of CKD. Clin J Am Soc Nephrol 2009;4:1523-1528.

-30 Agrawal V, Marinescu V, Agarwal M, McCullough PA: Cardiovascular implications of proteinuria: an indicator of chronic kidney disease. Nat Rev Cardiol 2009;6:301-311.

31 Bianchi S, Bigazzi R, Campese VM: Intensive Versus Conventional Therapy to Slow the Progression of Idiopathic Glomerular Diseases. Am J Kidney Dis 2010;55:671-681.

-32 Kalaitzidis RG, Bakris GL: Should proteinuria reduction be the criterion for antihypertensive drug selection for patients with kidney disease? Curr Opin Nephrol Hypertens 2009;18:386-391.

-33 Levey AS, Cattran D, Friedman A, Miller WG, Sedor J, Tuttle K, Kasiske B, Hostetter T: Proteinuria as a surrogate outcome in CKD: report of a scientific workshop sponsored by the National Kidney Foundation and the US Food and Drug Administration. Am J Kidney Dis 2009;54:205-226.

34 Staples A, Wong C: Risk factors for progression of chronic kidney disease. Curr Opin Pediatr 2010;22:161-169.

-35 Basturk T, Unsal A: Is insulin resistance a risk factor for the progression of chronic kidney disease? Kidney Blood Press Res 2011;34:111-115.

-36 Paterno JC, Bergamaschi CT, Campos RR, Higa EM, Soares MF, Schor N, Freire AO, Teixeira VP: Electroacupuncture and moxibustion decrease renal sympathetic nerve activity and retard progression of renal disease in rats. Kidney Blood Press Res 2012;35:355-364.

-37 Tylicki L, Lizakowski S, Rutkowski P, Renke M, Sulikowska B, Heleniak Z, Donderski R, Bednarski R, Przybylska M, Manitius J, Rutkowski B: The enhanced renin-angiotensin-aldosteron system pharmacological blockade-which is the best? Kidney Blood Press Res 2012;36:335-343.

-38 Bliss DZ, Stein TP, Schleifer CR, Settle RG: Supplementation with gum arabic fiber increases fecal nitrogen excretion and lowers serum urea nitrogen concentration in chronic renal failure patients consuming a lowprotein diet. Am J Clin Nutr 1996;63:392-398.

-39 Ali BH, Al Qarawi AA, Haroun EM, Mousa HM: The effect of treatment with gum Arabic on gentamicin nephrotoxicity in rats: a preliminary study. Ren Fail 2003;25:15-20.

40 Ali BH, Al Husseni I, Beegam S, Al Shukaili A, Nemmar A, Schierling S, Queisser N, Schupp N: Effect of gum arabic on oxidative stress and inflammation in adenine-induced chronic renal failure in rats. PLoS One 2013;8:e55242.

-41 Ali BH, Al Salam S, Al H, I, Kayed RR, Al Masroori N, Al Harthi T, Al Zaabi M, Nemmar A: Effects of Gum Arabic in rats with adenine-induced chronic renal failure. Exp Biol Med (Maywood) 2010;235:373-382.

-42 Teichberg S, Wingertzahn MA, Moyse J, Wapnir RA: Effect of gum arabic in an oral rehydration solution on recovery from diarrhea in rats. J Pediatr Gastroenterol Nutr 1999;29:411-417.

43 Schneeman BO: Fiber, inulin and oligofructose: similarities and differences. J Nutr 1999;129:1424S-1427S.

44 Nasir O, Artunc F, Wang K, Rexhepaj R, Foller M, Ebrahim A, Kempe DS, Biswas R, Bhandaru M, Walter M, Mohebbi N, Wagner CA, Saeed AM, Lang F: Downregulation of mouse intestinal $\mathrm{Na}(+)$-coupled glucose transporter SGLT1 by gum arabic (Acacia Senegal). Cell Physiol Biochem 2010;25:203-210. 


\section{Kidney \\ Blood Pressure Research}

45 Wright EM, Martin MG, Turk E: Intestinal absorption in health and disease--sugars. Best Pract Res Clin Gastroenterol 2003;17:943-956.

46 Martin MG, Wang J, Solorzano-Vargas RS, Lam JT, Turk E, Wright EM: Regulation of the human Na(+)-glucose cotransporter gene, SGLT1, by HNF-1 and Sp1. Am J Physiol Gastrointest Liver Physiol 2000;278:G591-G603.

47 Loflin P, Lever JE: HuR binds a cyclic nucleotide-dependent, stabilizing domain in the 3' untranslated region of $\mathrm{Na}(+)$ /glucose cotransporter (SGLT1) mRNA. FEBS Lett 2001;509:267-271.

-48 Hirsh AJ, Cheeseman CI: Cholecystokinin decreases intestinal hexose absorption by a parallel reduction in SGLT1 abundance in the brush-border membrane. J Biol Chem 1998;273:14545-14549.

49 Vayro S, Silverman M: PKC regulates turnover rate of rabbit intestinal Na+-glucose transporter expressed in COS-7 cells. Am J Physiol 1999;276:C1053-C1060.

50 Ferraris RP, Diamond JM: Specific regulation of intestinal nutrient transporters by their dietary substrates. Annu Rev Physiol 1989;51:125-141.

51 Ishikawa Y, Eguchi T, Ishida H: Mechanism of beta-adrenergic agonist-induced transmural transport of glucose in rat small intestine. Regulation of phosphorylation of SGLT1 controls the function. Biochim Biophys Acta 1997;1357:306-318.

52 Stumpel F, Kucera T, Gardemann A, Jungermann K: Acute increase by portal insulin in intestinal glucose absorption via hepatoenteral nerves in the rat. Gastroenterology 1996;110:1863-1869.

-53 Cheeseman CI: Upregulation of SGLT-1 transport activity in rat jejunum induced by GLP-2 infusion in vivo. Am J Physiol 1997;273:R1965-R1971.

-54 Lane RH, Dvorak B, MacLennan NK, Dvorakova K, Halpern MD, Pham TD, Philipps AF: IGF alters jejunal glucose transporter expression and serum glucose levels in immature rats. Am J Physiol Regul Integr Comp Physiol 2002;283:R1450-R1460.

55 Rexhepaj R, Artunc F, Metzger M, Skutella T, Lang F: PI3-kinase-dependent electrogenic intestinal transport of glucose and amino acids. Pflugers Arch 2007;453:863-870.

-56 Artunc F, Rexhepaj R, Volkl H, Grahammer F, Remy C, Sandulache D, Nasir O, Wagner CA, Alessi DR, Lang F: Impaired intestinal and renal glucose transport in PDK-1 hypomorphic mice. Am J Physiol Regul Integr Comp Physiol 2006;291:R1533-R1538.

57 Dieter M, Palmada M, Rajamanickam J, Aydin A, Busjahn A, Boehmer C, Luft FC, Lang F: Regulation of glucose transporter SGLT1 by ubiquitin ligase Nedd4-2 and kinases SGK1, SGK3, and PKB. Obes Res 2004;12:862-870.

58 Grahammer F, Henke G, Sandu C, Rexhepaj R, Hussain A, Friedrich B, Risler T, Metzger M, Just L, Skutella T, Wulff P, Kuhl D, Lang F: Intestinal function of gene-targeted mice lacking serum- and glucocorticoid-inducible kinase 1. Am J Physiol Gastrointest Liver Physiol 2006;290:G1114-G1123.

59 Sandu C, Rexhepaj R, Grahammer F, McCormick JA, Henke G, Palmada M, Nammi S, Lang U, Metzger M, Just L, Skutella T, Dawson K, Wang J, Pearce D, Lang F: Decreased intestinal glucose transport in the sgk3-knockout mouse. Pflugers Arch 2005;451:437-444.

60 Osswald C, Baumgarten K, Stumpel F, Gorboulev V, Akimjanova M, Knobeloch KP, Horak I, Kluge R, Joost HG, Koepsell H: Mice without the regulator gene Rsc1A1 exhibit increased Na+-D-glucose cotransport in small intestine and develop obesity. Mol Cell Biol 2005;25:78-87.

61 Veyhl M, Keller T, Gorboulev V, Vernaleken A, Koepsell H: RS1 (RSC1A1) regulates the exocytotic pathway of Na+-D-glucose cotransporter SGLT1. Am J Physiol Renal Physiol 2006;291:F1213-F1223.

-62 Wingertzahn MA, Teichberg S, Wapnir RA: Stimulation of non-sodium-dependent water, electrolyte, and glucose transport in rat small intestine by gum arabic. Dig Dis Sci 2001;46:1105-1112.

63 Koh-Banerjee P, Franz M, Sampson L, Liu S, Jacobs DR, Jr., Spiegelman D, Willett W, Rimm E: Changes in whole-grain, bran, and cereal fiber consumption in relation to 8-y weight gain among men. Am J Clin Nutr 2004;80:1237-1245.

64 McKeown NM, Meigs JB, Liu S, Saltzman E, Wilson PW, Jacques PF: Carbohydrate nutrition, insulin resistance, and the prevalence of the metabolic syndrome in the Framingham Offspring Cohort. Diabetes Care 2004;27:538-546.

65 Chandalia M, Garg A, Lutjohann D, von Bergmann K, Grundy SM, Brinkley LJ: Beneficial effects of high dietary fiber intake in patients with type 2 diabetes mellitus. N Engl J Med 2000;342:1392-1398.

66 Delzenne NM, Cani PD: A place for dietary fibre in the management of the metabolic syndrome. Curr Opin Clin Nutr Metab Care 2005;8:636-640.

67 Babiker R, Merghani TH, Elmusharaf K, Badi RM, Lang F, Saeed AM: Effects of Gum Arabic ingestion on body mass index and body fat percentage in healthy adult females: two-arm randomized, placebo controlled, doubleblind trial. Nutr J 2012;11:111. 


\section{Kidney \\ Blood Pressure Research}

68 Calame W, Thomassen F, Hull S, Viebke C, Siemensma AD: Evaluation of satiety enhancement, including compensation, by blends of gum arabic. A methodological approach. Appetite 2011;57:358-364.

69 Deaglio S, Aydin S, Vaisitti T, Bergui L, Malavasi F: CD38 at the junction between prognostic marker and therapeutic target. Trends Mol Med 2008;14:210-218.

70 Dinarello CA: The paradox of pro-inflammatory cytokines in cancer. Cancer Metastasis Rev 2006;25:307-313.

71 Katzav S: Vav: Captain Hook for signal transduction? Crit Rev Oncog 1995;6:87-97.

72 Kanai Y, Endou H: Heterodimeric amino acid transporters: molecular biology and pathological and pharmacological relevance. Curr Drug Metab 2001;2:339-354.

-73 Aka JA, Mazumdar M, Lin SX: Reductive 17beta-hydroxysteroid dehydrogenases in the sulfatase pathway: critical in the cell proliferation of breast cancer. Mol Cell Endocrinol 2009;301:183-190.

74 Lai JP, Thompson JR, Sandhu DS, Roberts LR: Heparin-degrading sulfatases in hepatocellular carcinoma: roles in pathogenesis and therapy targets. Future Oncol 2008;4:803-814.

75 Orlowski RZ, Kuhn DJ: Proteasome inhibitors in cancer therapy: lessons from the first decade. Clin Cancer Res 2008;14:1649-1657.

76 Sancho-Martinez I, Martin-Villalba A: Tyrosine phosphorylation and CD95: a FAScinating switch. Cell Cycle 2009;8:838-842.

77 Jin T, George F, I, Sun J: Wnt and beyond Wnt: multiple mechanisms control the transcriptional property of betacatenin. Cell Signal 2008;20:1697-1704.

78 Kim YS, Milner JA: Dietary modulation of colon cancer risk. J Nutr 2007;137:2576S-2579S.

-79 Nasir O, Wang K, Foller M, Bhandaru M, Sandulache D, Artunc F, Ackermann TF, Ebrahim A, Palmada M, Klingel K, Saeed AM, Lang F: Downregulation of angiogenin transcript levels and inhibition of colonic carcinoma by gum arabic (Acacia senegal). Nutr Cancer 2010;62:802-810.

-80 Cummings JH, Bingham SA, Heaton KW, Eastwood MA: Fecal weight, colon cancer risk, and dietary intake of nonstarch polysaccharides (dietary fiber). Gastroenterology 1992;103:1783-1789.

-81 Fuchs CS, Giovannucci EL, Colditz GA, Hunter DJ, Stampfer MJ, Rosner B, Speizer FE, Willett WC: Dietary fiber and the risk of colorectal cancer and adenoma in women. N Engl J Med 1999;340:169-176.

-82 Finley JW, Burrell JB, Reeves PG: Pinto bean consumption changes SCFA profiles in fecal fermentations, bacterial populations of the lower bowel, and lipid profiles in blood of humans. J Nutr 2007;137:2391-2398.

83 Ishikawa S, Asano T, Takenoshita S, Nozawa Y, Arihara K, Itoh M: Egg yolk proteins suppress azoxymethaneinduced aberrant crypt foci formation and cell proliferation in the colon of rats. Nutr Res 2009;29:64-69.

-84 Pool-Zobel BL: Inulin-type fructans and reduction in colon cancer risk: review of experimental and human data. Br J Nutr 2005;93:S73-S90.

85 Usami M, Kishimoto K, Ohata A, Miyoshi M, Aoyama M, Fueda Y, Kotani J: Butyrate and trichostatin A attenuate nuclear factor kappaB activation and tumor necrosis factor alpha secretion and increase prostaglandin E2 secretion in human peripheral blood mononuclear cells. Nutr Res 2008;28:321-328.

-86 Basson MD, Emenaker NJ, Hong F: Differential modulation of human (Caco-2) colon cancer cell line phenotype by short chain fatty acids. Proc Soc Exp Biol Med 1998;217:476-483.

87 Campbell CT, Aich U, Weier CA, Wang JJ, Choi SS, Wen MM, Maisel K, Sampathkumar SG, Yarema KJ: Targeting pro-invasive oncogenes with short chain fatty acid-hexosamine analogues inhibits the mobility of metastatic MDA-MB-231 breast cancer cells. J Med Chem 2008;51:8135-8147.

88 Chen JS, Faller DV, Spanjaard RA: Short-chain fatty acid inhibitors of histone deacetylases: promising anticancer therapeutics? Curr Cancer Drug Targets 2003;3:219-236.

89 Abdel-Rahman AM, el Sahrigy SA, Bakr SI: A comparative study of two angiogenic factors: vascular endothelial growth factor and angiogenin in induced sputum from asthmatic children in acute attack. Chest 2006;129:266271.

-90 Hooper LV, Stappenbeck TS, Hong CV, Gordon JI: Angiogenins: a new class of microbicidal proteins involved in innate immunity. Nat Immunol 2003;4:269-273.

-91 Hoshino M, Takahashi M, Aoike N: Expression of vascular endothelial growth factor, basic fibroblast growth factor, and angiogenin immunoreactivity in asthmatic airways and its relationship to angiogenesis. J Allergy Clin Immunol 2001;107:295-301.

92 Liote F, Champy R, Moenner M, Boval-Boizard B, Badet J: Elevated angiogenin levels in synovial fluid from patients with inflammatory arthritis and secretion of angiogenin by cultured synovial fibroblasts. Clin Exp Immunol 2003;132:163-168.

-93 Maruotti N, Cantatore FP, Crivellato E, Vacca A, Ribatti D: Angiogenesis in rheumatoid arthritis. Histol Histopathol 2006;21:557-566. 


\section{Kidney \\ Blood Pressure Research}

94 Olson KA, Verselis SJ, Fett JW: Angiogenin is regulated in vivo as an acute phase protein. Biochem Biophys Res Commun 1998;242:480-483.

$\$ 95$ Suzumori N, Zhao XX, Suzumori K: Elevated angiogenin levels in the peritoneal fluid of women with endometriosis correlate with the extent of the disorder. Fertil Steril 2004;82:93-96.

$\$ 96$ Koutroubakis IE, Xidakis C, Karmiris K, Sfiridaki A, Kandidaki E, Kouroumalis EA: Serum angiogenin in inflammatory bowel disease. Dig Dis Sci 2004;49:1758-1762.

-97 Edelman SM, Kasper DL: Symbiotic commensal bacteria direct maturation of the host immune system. Curr Opin Gastroenterol 2008;24:720-724.

-98 Adler HS, Steinbrink K: Tolerogenic dendritic cells in health and disease: friend and foe! Eur J Dermatol 2007;17:476-491.

99 Banchereau J, Briere F, Caux C, Davoust J, Lebecque S, Liu YJ, Pulendran B, Palucka K: Immunobiology of dendritic cells. Annu Rev Immunol 2000;18:767-811.

100 van Duivenvoorde LM, Han WG, Bakker AM, Louis-Plence P, Charbonnier LM, Apparailly F, van der Voort EI, Jorgensen C, Huizinga TW, Toes RE: Immunomodulatory dendritic cells inhibit Th1 responses and arthritis via different mechanisms. J Immunol 2007;179:1506-1515.

101 Bhandaru M, Pasham V, Yang W, Bobbala D, Rotte A, Lang F: Effect of azathioprine on $\mathrm{Na}(+) / \mathrm{H}(+)$ exchanger activity in dendritic cells. Cell Physiol Biochem 2012;29:533-542.

102 E X, Cao Y, Meng H, Qi Y, Du G, Xu J, Bi Z: Dendritic cells of synovium in experimental model of osteoarthritis of rabbits. Cell Physiol Biochem 2012;30:23-32.

103 Rotte A, Pasham V, Bhandaru M, Bobbala D, Zelenak C, Lang F: Rapamycin sensitive ROS formation and $\mathrm{Na}(+) / \mathrm{H}(+)$ exchanger activity in dendritic cells. Cell Physiol Biochem 2012;29:543-550.

104 Schmid E, Bhandaru M, Nurbaeva MK, Yang W, Szteyn K, Russo A, Leibrock C, Tyan L, Pearce D, Shumilina E, Lang F: SGK3 regulates Ca(2+) entry and migration of dendritic cells. Cell Physiol Biochem 2012;30:1423-1435.

105 Szteyn K, Schmid E, Nurbaeva MK, Yang W, Munzer P, Kunzelmann K, Lang F, Shumilina E: Expression and functional significance of the $\mathrm{Ca}(2+)$-activated $\mathrm{Cl}(-)$ channel ANO6 in dendritic cells. Cell Physiol Biochem 2012;30:1319-1332.

106 Yang W, Bhandaru M, Pasham V, Bobbala D, Zelenak C, Jilani K, Rotte A, Lang F: Effect of thymoquinone on cytosolic $\mathrm{pH}$ and $\mathrm{Na}+\mathrm{H}+$ exchanger activity in mouse dendritic cells. Cell Physiol Biochem 2012;29:21-30.

107 Zhao H, Li M, Wang L, Su Y, Fang H, Lin J, Mohabeer N, Li D: Angiotensin II induces TSLP via an AT1 receptor/ NF-KappaB pathway, promoting Th17 differentiation. Cell Physiol Biochem 2012;30:1383-1397.

108 Tarbell KV, Yamazaki S, Steinman RM: The interactions of dendritic cells with antigen-specific, regulatory T cells that suppress autoimmunity. Semin Immunol 2006;18:93-102.

109 Remondo C, Cereda V, Mostbock S, Sabzevari H, Franzusoff A, Schlom J, Tsang KY: Human dendritic cell maturation and activation by a heat-killed recombinant yeast (Saccharomyces cerevisiae) vector encoding carcinoembryonic antigen. Vaccine 2009;27:987-994.

110 Chorny A, Gonzalez-Rey E, Delgado M: Regulation of dendritic cell differentiation by vasoactive intestinal peptide: therapeutic applications on autoimmunity and transplantation. Ann N Y Acad Sci 2006;1088:187-194.

111 Schuurhuis DH, Fu N, Ossendorp F, Melief CJ: Ins and outs of dendritic cells. Int Arch Allergy Immunol 2006;140:53-72.

112 Gelin C, Sloma I, Charron D, Mooney N: Regulation of MHC II and CD1 antigen presentation: from ubiquity to security. J Leukoc Biol 2009;85:215-224.

113 Blanco P, Palucka AK, Pascual V, Banchereau J: Dendritic cells and cytokines in human inflammatory and autoimmune diseases. Cytokine Growth Factor Rev 2008;19:41-52.

114 Lehner T: Special regulatory T cell review: The resurgence of the concept of contrasuppression in immunoregulation. Immunology 2008;123:40-44.

115 Li MO, Flavell RA: Contextual regulation of inflammation: a duet by transforming growth factor-beta and interleukin-10. Immunity 2008;28:468-476.

116 Steinman RM, Nussenzweig MC: Avoiding horror autotoxicus: the importance of dendritic cells in peripheral T cell tolerance. Proc Natl Acad Sci U S A 2002;99:351-358.

117 Xuan NT, Shumilina E, Nasir O, Bobbala D, Gotz F, Lang F: Stimulation of mouse dendritic cells by Gum Arabic. Cell Physiol Biochem 2010;25:641-648.

118 Ballal A, Bobbala D, Qadri SM, Foller M, Kempe D, Nasir O, Saeed A, Lang F: Anti-malarial effect of gum arabic. Malar J 2011;10:139. 